\title{
"Applications of good corporate governance relating to shareholders, commissioners, and directors of limited liability companies in Indonesia"
}

\begin{tabular}{|c|c|}
\hline AUTHORS & $\begin{array}{l}\text { Joseph Andy Hartanto (D https://orcid.org/0000-0001-9142-0067 } \\
\text { Sulaksono Sulaksono iD https://orcid.org/0000-0001-6397-6391 }\end{array}$ \\
\hline ARTICLE INFO & $\begin{array}{l}\text { Joseph Andy Hartanto and Sulaksono Sulaksono (2019). Applications of good } \\
\text { corporate governance relating to shareholders, commissioners, and directors of } \\
\text { limited liability companies in Indonesia. Problems and Perspectives in } \\
\text { Management, 17(3), 410-420. doi:10.21511/ppm.17(3).2019.33 }\end{array}$ \\
\hline DOI & http://dx.doi.org/10.21511/ppm.17(3).2019.33 \\
\hline RELEASED ON & Monday, 23 September 2019 \\
\hline RECEIVED ON & Saturday, 06 July 2019 \\
\hline ACCEPTED ON & Monday, 09 September 2019 \\
\hline LICENSE & $\begin{array}{l}(\mathrm{cc}) \mathrm{EY} \\
\text { This work is licensed under a Creative Commons Attribution } 4.0 \text { International } \\
\text { License }\end{array}$ \\
\hline JOURNAL & "Problems and Perspectives in Management" \\
\hline ISSN PRINT & $1727-7051$ \\
\hline ISSN ONLINE & $1810-5467$ \\
\hline PUBLISHER & LLC "Consulting Publishing Company "Business Perspectives" \\
\hline FOUNDER & LLC "Consulting Publishing Company "Business Perspectives" \\
\hline
\end{tabular}

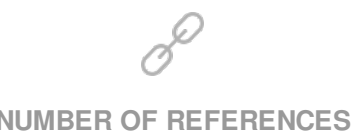

57

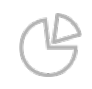

NUMBER OF FIGURES

0

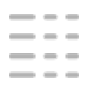

NUMBER OF TABLES

0

(C) The author(s) 2022. This publication is an open access article. 


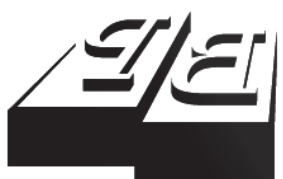

BUSINESS PERSPECTIVES

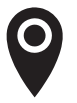

LLC "CPC "Business Perspectives" Hryhorii Skovoroda lane, 10, Sumy, 40022, Ukraine

www.businessperspectives.org

Received on: $6^{\text {th }}$ of July, 2019 Accepted on: $9^{\text {th }}$ of September, 2019

(C) Joseph Andy Hartanto, Sulaksono, 2019

Joseph Andy Hartanto, Ph.D., Senior Lecturer, Department of Law, Universitas Narotama, Surabaya, Indonesia.

Sulaksono, Ph.D., Senior Lecturer, Department of Law, Universitas Dr. Soetomo, Surabaya, Indonesia.

\section{APPLICATIONS OF GOOD CORPORATE GOVERNANCE RELATING TO SHAREHOLDERS, COMMISSIONERS, AND DIRECTORS OF LIMITED LIABILITY COMPANIES IN INDONESIA}

\begin{abstract}
This critical analysis seeks to explore the inclusivity and feasibility of the legal application of organizational governance principles related to limited liability companies (LLCs) in Indonesia, which are considered essential pillars of Indonesia's economic stability. The investigators employed the non-probability purposive sampling to select 150 study participants from a population of 250 administrative panel members working in PT Bank Rakyat Indonesia and PT Bank Mandiri. Structured and semistructured questionnaires were constructed and distributed online through emails. The subjects' responses were coded manually, using the NVivo software for ease of analysis. The result showed that (1) $84.5 \%$ of participants believed that ineffective relationship building approaches, corruption, and inadequate information disclosure mechanisms among internal and external shareholders formed the main challenges to implementation of corporate governance principles in Indonesian LLCs, (2) 97.8\% of the respondents believed the Indonesian Company Law (ICL) had achieved significant milestones in guiding the application of sound corporate governance principles by explicitly outlining the roles and responsibilities of stakeholders and providing sufficient protection for minority stakeholders, and (3) 78\% of participants agreed that the ICL has introduced and reinforced critical rights and protections to shield shareholders from unfair regulations internally formulated by a company. In its findings, the investigation confirmed that poorly structured information sharing systems, fraud, and ineffective relationship building were the main factors that contributed to current inadequacies. $84.5 \%$ of the respondents believed that ineffective relationship building approaches, corruption, and inadequate information disclosure mechanisms among internal and external shareholders formed the main challenges, trends, and issues to the implementation of corporate governance principles in Indonesian LLCs. The study also confirmed that the implementation of GCG related legislations had reinforced the professional duties and obligations of stakeholders, alongside offering legal protections for minority business actors.
\end{abstract}

Keywords

limited liability company, Good Corporate Governance, Indonesian Company Law

\section{JEL Classification K22, O16, G34}

\section{INTRODUCTION}

As a principle of employee and shareholder management, Good Corporate Governance (GCG), as explained in Indonesia's Article 15 of Act No. 25 of 2007, defines a limited liability company (LLC) as any individual or group of people who initiate any form of foreign or domestic investment (Chang, 2018). The primary GCG doctrines include fairness, responsibility, accountability, and transparency. These rules also govern crucial company aspects, such as the division of duties, independence, and corporate structure management (Cuervo, 2002). The applications and evaluation of the concept of GCG among Indonesian 
public and foreign investment limited liability companies are regulated by the Capital Market Law and Investment Law, respectively (Retno \& Priantinah, 2012). On the other hand, non-bank corporations and banking establishments are planned and synchronized by the Financial Services Authority.

The Capital Market Law is a more comprehensive and detailed set of regulations and mandates public LLCs to adhere to the rules and regulations stipulated by the Indonesian Stock Exchange. These legal provisions ensure that public enterprises operate in compliance with the Indonesian Stock Exchange and Financial Services Authority's provisions. According to Ashbaugh-Skaife et al. (2006), these directives require public LLCs to be guided by independent directors and commissioners. Moreover, GCG laws should be aimed at establishing an operational remuneration and nomination committee, an internal assessment unit, an audit commission, and a corporate secretary (Sari et al., 2018). However, since 2007, the Indonesian limited liability companies have not undergone significant modifications of the GCG principles currently in place to align corporate governance strategies with company performance and productivity (Du Plessis, Hargovan, \& Harris, 2018). In line with the applications and implementations of GCG ideologies to guide the operations of the country's limited liability companies, this research will narrow its focus to examine the legal provisions that govern the implementation of the GCG doctrines, and how they support active economic development.

\section{RESEARCH GAP AND OBJECTIVES}

The GCG principles currently in place for Indonesian LLCs have not undergone significant modifications since 2007 to align corporate governance strategies with company performance and productivity (Du Plessis et al., 2018). In line with the application and implementation of GCG ideologies guiding the operations of the country's LLCs, therefore, this study seeks to fill a gap in the research. The aim of this research was to look into how the legal application of corporate governance principles related to LLCs in Indonesia.

The fundamental questions that the investigation sought to answer include:

1. What are some of the common challenges, trends, and issues that significantly impacted both public and foreign investment LLCs?

2. What are some of the dominant perspectives regarding the risks and achievements of the ICL in supporting long-term sustainability and profitability of LLCs as a result of the appropriate application of legally acceptable corporate governance principles?

3. What are the jurisdictional rights of shareholders and directors who seek to comply with corporate governance regulations within their respective administrative roles as sole overseers of company operations and management?

\section{LITERATURE REVIEW}

Jao and Pagalung (2011) state that contemporary developments in ICL are founded on European civil legal infrastructures. In 1847, the corporate form of the ICL was integrated into the business environment under the Indonesian Wetboek van Koophandel, Kitab Undang-Undang Hukum Dagang (Commercial Code) (Jao \& Pagalung, 2011). Because the country was under the rule of the Dutch Republic at that time, the implementation of these codes was influenced mainly by the Dutch Commercial Code. Since its introduction, the ICL has undergone multiple adjustments to suit the progressive policies and requirements that govern the procedures for implementation of GCG practices.

In 1995, Indonesia's ruling government passed a new law, known as the UUPT (Undang-Undang Tentang Perseroan Terbatas), that was designed to regulate the operations of public and foreign investment LLCs. The UUPT became the first amendment of the KUHD after the country attained its independence in 1945 (Kaihatu, 2006). In 2007, the rule underwent significant adjustments and became known as the Company Law (CL), which made a statutory guideline for differ- 
ent types of LLCs (Kaihatu, 2006). The ICL emphasized the importance of minority stakeholder protections and the need to uphold the interests of an enterprise's workers, administrators, and the community as a whole, through the implementation of corporate governance best practices.

Du Plessis et al. (2018) carried out an investigation, which confirmed that the main goals of corporate governance principles (transparency, accountability, fairness, and responsibility) include overseeing the overall development of Indonesian companies. Bals and Tate (2017) presented their agreement with these findings when they confirmed that employing GCG doctrines could drive the revival of collapsed corporations. These predictions are supported by the existence of a multiplier impact in various industries. Therefore, the benefits of GCG, as recorded in LLCs, are also likely to be experienced in others.

Reliable statistics provided by Nasution and Setiawan (2007) indicate that the number of LLCs in Indonesia has continued to grow over the years, and is currently 23,941; over 100 governmental enterprises are operating as LLCs. Nasution and Setiawan (2007) also confirmed the existence of 507 publicly-listed corporations. The statistics concerning the number of public and private LLCs provide evidence that the execution of GCG in these establishments will enhance an industry's value and performance by reinforcing the level of confidence and loyalty among stakeholders, creditors, and suppliers, therefore, enabling them to obtain development loans. Ramage (2007) corroborates these findings by stating that practical implementation of GCG policies will reduce the severity of common challenges such as corruption, which have impaired the growth of private and public sectors in Indonesia for decades. However, as indicated by Gourevitch and Shinn (2005), the primary issues that have reduced the ability of GCG regulations to achieve their legal mandates include the presence or absence of reinforcement mechanisms put in place by specific corporations to increase the strength and effectiveness of GCG implementation.

Annisa and Kurniasih (2012) incorporate Lawrence Friedman's legal system theory to evaluate the challenges facing execution of GCG principles in
Indonesian LLCs. According to the researchers, a company's management is likely to fail in implementing GCG principles if it does not adhere to the three significant elements of policy directives, including the legal culture, structure, and substance. As Annisa and Kurniasih (2012) maintain, the integration of GCG principles is not only limited to the general terms or conditions, which only serve as a guideline without any legal investment in the directives stipulated by international standard GCG doctrines. This means that the establishment of GCG must adhere to existing legal requirements to provide a binding force for all entities involved in the management and operation of LLCs, including shareholders, BOCs, and BODs.

The recent amendments to the ICL and anticipated adjustments have been focused on creating a business-friendly environment. According to $\mathrm{Al}$ Daoud et al. (2015), the future of the Indonesian economy is brighter, considering that most public and foreign investment LLCs have demonstrated increased adoption and appropriate application of GCG doctrines. However, despite current positive perceptions regarding the effectiveness of ICL in guiding and reinforcing GCG ideologies within an organization, many Southeast Asian investors exhibit a preference for Singapore's holding companies (Chi et al., 2015). Despite the economic stability rate that has been supported by effective implementation of GCG practices and the sound development of critical infrastructures that support trade, it is not apparent at this time whether foreign investors prefer incorporating their enterprises in Indonesia (Daily et al., 2003). The main concern that has been expressed by foreign businesspersons is whether the country has implemented adequate strategies to protect the interests of foreign-owned establishments.

According to Fan and Wong (2005), the process of strengthening a company's corporate governance principles of accountability, transparency, and fairness can significantly be facilitated by the board of directors and lower-level administrators. The ICL defines the BOD's functions and obligations as binding tasks designed to improve a company's management. The ICL also require the BOD and BOC to act responsibly and in good faith. Carter et al. (2003) state that these entities are accountable for the accuracy and relevance of 
all information that is provided to internal and foreign investors, mainly as they apply to corporate governance strategies, shareholding, and financial analyses. Moreover, the BOD is required to ensure minor and major stakeholders are treated equally in terms of access to and distribution of timely and accurate communications.

Farrar (2008) focused on comparing the Indonesian and Singapore laws that regulate limited liability enterprises, corporate governance practices, and shareholder protection. The research was particularly interesting as it revealed that the nature and operations of a legal jurisdiction are significantly impacted by company law. The exploration concluded that the regions that complied with a mutual rule were more capable of addressing issues concerning GCG and stakeholder protection, resulting in an improved level of market capitalization and investment. Also, according to Mallin (2011), the primary differences between the Singapore and Indonesian foundations of company law arise from the common law upon which their legislation is founded, with the latter being based on European civil law and the former on English civil law. Since the formulation and introduction of the ICL, it has focused on protecting the interests of society, workers, employees, shareholders, and the operations of LLCs through fair competition and oversight.

In the case of Indonesia, Company Law was introduced in Malacca, Singapore, and Penang in 1866 through the Indian Companies Act (Calder, 2008). After its implementation, the legal regulations underwent several revisions, resulting in the formation of the Malaysian Company Act. Even though Singapore withdrew from the Malaysian Federation, it borrowed numerous elements of the Malaysian law of 1965 (Puspitaningrum \& Atmini, 2012). Currently, LLCs in Singapore are regulated by the Companies Act, which significantly differs from that of Indonesia, although both are based on similar principles (Mitton, 2002). Moreover, although English law decisions are not as binding as those of the European jurisdictions that govern ICL, they are both flexible to a particular degree and often refer to past cases that were decided by more established authorities. Therefore, it is evident that Singapore and Indonesia are governed by distinct legal origins, procedures, and traditions.
A scientific exploration accomplished by Iu and Batten (2001) with an underlying goal of examining specific provisions and efficiencies of Indonesian and Singapore corporate governance regulations regarding company management, revealed the following trends. First, the Indonesian corporate regulations require all LLCs be governed by two distinct bodies of authority including the board of commissioners and board of directors, commonly known as the BOC-Komisaris and BOD-Direksi, respectively (Bratton \& McCahery, 2002). The main functions, powers, and roles of BOD-Direksi include representing or managing the enterprise, while the BOC-Komisaris is supposed to fulfill professional responsibilities in the best interests of the company (Luo et al., 2015). Specifically, the ICL requires its directors to get the necessary approvals from relevant entities such as shareholders before authorizing procurement or transfer of company assets when they exceed half the net assets owned by an enterprise (Bernstein \& Cashore, 2012). The ICL also requires the BOC to manage and guide the BOD-Direksi to ensure that the BOD properly discharges its duties in compliance with corporate governance requirements.

On the other hand, Singapore Company Law adopts a one-tier form of governance headed by a single BOD, which can be replaced, fired, or selected at the company's general meetings (Young et al., 2004). Moreover, in Singapore, regular schedules are inconsequential, since a director can be used to refer to any individual occupying the top-most position within the enterprise. Thus, company shareholders, in collaborations with the $\mathrm{BOD}$, can play a part in the company's management by making judgments that override those of the BOD-Direksi. Therefore, while liabilities and duties extend to officially appointed company directors in Indonesia, in Singapore, these obligations are associated with anyone who carries out directorial commitments, whether they have been formally nominated for the position or not.

According to Johnson et al. (2000), in Singapore, the BOD is expected to attend to their professional obligations while constantly considering the culture, policies, and goals of the company. Additionally, the BOD are obliged and always fulfill their due diligence and reasonable care responsibilities. Violating these duties may render these 
bodies liable to existing penalties unless offered relief by the court systems or a shareholders' pardon (Arevalo \& Aravind, 2011). Nevertheless, the accused directors must prove beyond a reasonable doubt that their actions wholly considered the views and policies of the corporation (Waagstein, 2011). The failure of a member of the BOD to act diligently and logically, for instance, when one deliberately fails to reveal conflicting interests, or to follow the due process required to procure or change ownership of company properties, then he or she can be subject to criminal liability.

In their comparison of the effectiveness of Indonesian and Singapore Company Law, including and not restricted to their ability to guide corporate governance responsibilities in LLCs, Sawicki (2009) concludes that "Indonesia's framework of directors' duties is less robust than that of Singapore. First, in contrast to Singapore Law, Indonesian Law does not provide for shadow directors or de facto directors" (p. 229). In essence, foreign investors who seek to penetrate the Indonesian market must be able to accept and tolerate the fact that any fiduciary duties may not bind individuals who regulate a company's procedures. Gilson (2001) contributes to this discussion by maintaining that, "unlike the case in Singapore, Indonesian companies are not prohibited from making loans to directors. This presents a risk to foreign shareholders, as directors or commissioners may, in an Indonesian company, misuse their office or authority to un-procedurally allocate themselves loans" (p. 335). Thus, even though directors and managers are legally obligated to ensure that the enterprise is supported in good faith and in compliance with internal policies and expectations, overseas stakeholders should be aware of the likelihood of instances where there is confusion regarding the actual duties and responsibilities of directors.

Moreover, the ICL seems unclear on the scope of the BOD's practices, while Singapore has integrated adequate elements of English common law that explicitly state the roles and expectations of company directors (Claessens et al., 2001; Claessens \& Fan, 2002). In Indonesia, it appears that foreign stakeholders are exposed to increased reservations due to the lack of developed case law that stipulates precisely what actions constitute legally punishable actions (Rama, 2012). Therefore, overseas business financiers may prefer investing in Singapore LLCs. Moreover, Singapore Company Law is perceived as a crucial component of an operational corporate governance framework that is focused on preventing businessmen from exploiting an enterprise's resources without the consent or awareness of company shareholders ( $\mathrm{Wu}, 2005 \mathrm{a})$. Given the lack of clear applications and definitions of additional guidelines and fiduciary duties that provide directives regarding the responsibilities of company shareholders and administrators, Indonesian laws will have failed to merit shareholders' reinforced confidence.

In a similar study comparing regulations that manage derivative actions in Singapore and Indonesia, Walter (2008) established that Indonesia should make significant changes to its Company Law to enable it to support GCG strategies and approaches effectively. Young et al. (2004) indicate that "Singapore's derivative action is available to all shareholders whereas Indonesia's derivative suit is only open to a single substantial shareholder who carries $10 \%$ of shares with valid voting rights" (p. 15). The situation has resulted in significant barriers to marginal financiers who would like to manage derivative vehicles. As a result, minority stakeholders are left with little power to foster corporate governance implementation with Indonesian LLCs (Wahyudin \& Solikhah, 2017). Thus, international stockholders who may choose to take up minor stakes in their Indonesia-based enterprises may consider this a significant threat.

Moreover, confirming the extent to derivative actions by critical supervisory boards in Indonesia regulate the activities of the BOC both within and outside their corporations is complex. As indicated by De Andres and Vallelado (2008), "derivative litigation can be enforced against individual members of the board of commissioners liable for wrongdoing or negligence causing damages to the company, which conflicts with provisions stating that that a single commissioner cannot act on his own and has to act based on the decision of the commissioners as a whole" (p. 2573). The ICL has also failed to manage derivative action procedures due to the lack of directives that stipulate the costs associated with such events (Darmadi, 2013). Such 
a situation may discourage foreign investors as they will perceive the Indonesian provisions in derivative actions as almost impossible to navigate.

Many LLCs in Indonesia are controlled by individuals with familial connections and have implemented above-average strategies to incorporate the principles of GCG in their operations (Nasution, 2001). Thus, the regulatory and legislative enforcement and execution procedures that seek to enhance corporate governance frameworks should be making in improved governance (Xie et al., 2003). Moreover, the relevant policymakers and stakeholders should carefully examine the association between financial reporting, corruption, and governmental involvements as the basis for improvement interventions ( $\mathrm{Wu}, 2005 \mathrm{~b})$. The private and public sector should stress the need for accurate financial records, duty allocations, and disclosure practices to increase transparent communications.

\section{METHODS}

\subsection{Study design}

Past examinations of the application of regulations to the direct implementation of corporate governance best practices have focused on assessing existing relationships between the shareholders, commissioners, and directors of LLCs (Wulandari, 2006). Nevertheless, this descriptive exploration will adopt both qualitative and quantitative methods. As emphasized by Creswell and Plano Clark (2017), this form of mixed study design is useful for supplementing, examining, and integrating both qualitative and quantitative data through focus group discussions and surveys, respectively. Specifically, this research will apply triangulation design to come up with complementary findings for each of the three research questions formulated for this investigation. Therefore, by using the triangulation form of mixed study research, we will be able to compare the outcomes of each method and reduce the negative effects of qualitative or quantitative study methods, including a lack of generalizability and small-sample sizes. To implement and evaluate the efficiency of corporate governance infrastructures, primary data were employed to examine how Indonesian LLCs integrate existing legal provisions.

\subsection{Data collection tools}

The researchers incorporated both open and close-ended questionnaires to collect information from the study participants. The investigators ensured validity and reliability by structuring each query around the three objectives of the research in a way that ensured the collective of detailed and consistent data. The development of these questionnaires was founded on previous conclusions made from intensive systematic analyses that confirmed transparency, impartiality, responsibility, and obligation as among the primary pillars of GCG. Moreover, the formulation of these questions considered five crucial categories of impact, such as informing policy development, promoting economic benefits, knowledge acquisition, enhancing social cohesion, capacity building, and improving knowledge acquisition concerning the benefits of good corporate governance principles in Indonesian LLCs. The research questionnaires were mailed to 150 study participants selected from the PT Bank Rakyat and PT Bank Mandiri.

\subsection{Study respondents selection}

For this study, the potential research respondents were required to fulfill the following inclusion criteria:

1. Must have worked in an Indonesian LLC for the past decade.

2. Must have held a leadership capacity in their respective company for at least a year.

3. Must be conversant with fundamental organizational details relevant for this investigation.

These subjects were selected using a non-probability purposive sampling technique. According to Etikan et al. (2016), this style of subject selection is appropriate for studies with limited time, space, and budgetary resources as it selects individuals based on the basis of their willingness, motivation, and commitment to take part in the research process. Factors such as the level of education and gender were not applied as determinants of participation. Nevertheless, the names, employee numbers, and positions within the company were kept private due to confidentiality re- 
quirements. Among the 150 participants who received the study questionnaires, 127 submitted their responses within the stipulated timeframe of three working days. The investigative team coded the gathered responses and analyzed them using NVivo software and multiple regression analyses.

\section{DATA ANALYSIS}

The researchers incorporated both manual and computerized data analysis to compare and contrast the statistical findings. The NVivo software was applied to provide accurate and rigorous information. The NVivo qualitative data analysis tool will be used only after investigators identify keywords or concepts in the provided responses, and mark them as relevant to the GCG research. Later on, the researchers created various data fragments and assigned them nodes in NVivo. The investigators then identified and selected fragments, which contained an idea directly or indirectly associated with GCG principles. The resulting information was further analyzed to reduce the redundancy caused by synonyms or unnecessary word duplication.

\section{FINDINGS}

The results revealed the following interesting trends: (1) $84.5 \%$ of the respondents believed that ineffective relationship building approaches, corruption, and inadequate information disclosure mechanisms among internal and external shareholders formed the main challenges to implementation of corporate governance principles in Indonesian LLCs, (2) $97.8 \%$ of the respondents believed the ICL had achieved significant milestones in guiding the application of sound corporate governance principles by explicitly outlining the roles and responsibilities of stakeholders and providing sufficient protection for minority stakeholders, and (3) $78 \%$ of the research participants agreed that the ICL has introduced and reinforced. A majority of the research subjects acknowledged critical rights and protections to shield shareholders from unfair regulations internally formulated by a company the ICL provision that offers stakeholders the right to file legal suits against the GSM, BOD, and BOC. These rights apply in cases where the affected stake- holders are convinced beyond a reasonable doubt that a reduction in the business's quality or efficiency has been caused by unfair and inconsiderate resolutions made by the BOD, BOC, and GMS. The primary study limitation was the use of a relatively small sample size to find out the key perceptions of LLC leaders' perceptions of GCG.

\section{DISCUSSION}

The findings of this investigation revealed collaborated past researches, which attributed the factors including corruption and poor relations to be the main hindrances to the application of GCG principles. Joseph et al. (2016) presented their concern regarding the impacts of corruption on the implementation of ethical corporate governance values in Indonesian LLCs. According to these scholars, fraud significantly impairs the capacity of relevant institutions and regulations to investigate GCG provisions while providing potential investors with asset safeguards. Therefore, Indonesian LLCs should routinely and consistently enforce reporting and disclosure requirements that reinforce the independence of company directors and minority shareholders (Zattoni \& Cuomo, 2010; Honggowati et al., 2017).

The research also revealed the significant achievements of the ICL in fostering the implementation of GCG. Since its introduction, the ICL has undergone multiple adjustments to suit the progressive policies and requirements that govern the procedures for implementation of GCG practices, which is evidently a step in the right direction. Overall, the Indonesian Company Law (ICL) and Articles of Association has successfully provided specific GCG rules that can be applied to any form of LLC within Indonesia (Haniffa \& Cooke, 2005). These laws stipulate the liabilities, responsibilities, rights, roles, and duties for crucial entities, including the Board of Commissioners (BOC), Board of Directors (BOD), and General Meeting of Shareholders (GSM) (Siregar \& Utama, 2008). In validating the conclusions by Rosser and Edwin (2010), this investigation, therefore, posits that the Investment Law has effectively reinforced the provisions of the ICL as an official overseer of GCG applications in foreign investment firms. 
Lastly, although this exploration confirmed that there are several critical rights and protections formulated in each LLC to protect stakeholders and administrators from unfair regulations, there is still a lot to be done. Gillespie (2012) addresses these concerns in their critique of the efficiency of Indonesia's BOD and BOC as currently constituted. According to Gillespie (2012), the differences in the functions and scope of operations of these bod- ies are not clearly outlined in the Company Law. Also, LLCs that are controlled by a few individuals or families have not adequately distinguished between management and ownership, thus compromising the execution of transparency and accountability policies (Okpara, 2011). In such establishments, the administrators are inclined to operate in compliance with the wishes and demands of significant stakeholders (Soesastro, 2003).

\section{CONCLUSION}

The Indonesian economy has recorded significant growth in the past years, which is a development associated with the successful implementation of the GCG principles of fairness, independence, investor interest protection, and community sustainability. The increasing execution of GCG approaches by foreign investment and public LLCs has created a multiplier effect within Indonesian industries, subsequently resulting in economic unity and steady progress. The ICL was formulated to establish a favorable environment that is free of corruption, compromising familial relationships, and transparency issues. Indonesian LLCs formulate stringent measures against the identified factors to reduce their adverse impacts on performance and employee relations. This way, Indonesian LLCs will enhance the degree of enterprise legal liability of both regional and overseas stockholders.

This research, conducted to examine the effectiveness and practicality of proper applications of organizational governance principles related to LLCs in Indonesia, revealed exciting trends. Although the ICL has achieved significant milestones as it pertains to the stakeholder's right protection and the execution of GCG doctrines of culpability, deference, and fair-mindedness, it still requires specific changes to enhance its capabilities and scope. The ICL should focus on fulfilling additional commitments, including limitations on nominee-share proprietorship agreements and the regulation that requires international direct investment procedures to be carried out by Indonesian LLCs.

A comparison between Singapore and Indonesian Company Laws indicates primary deficiencies of the latter in regulating adverse consequences for derivative actions, especially for minority shareholders. The study, therefore, proposes the formulation of fairness policies for lower-level employees and the BOD, especially in instances of bankruptcy. Undertaking these steps will place Indonesia in the global map for countries with favorable business environments. The primary implication for future research is the uncovered need to formulate and execute appropriate provisions, notices, and guidance that reinforce the inadequacies identified in this research as initial attempts to enhance investor confidence. Moreover, it is important to increase research in this particular domain to enable both investors and shareholders to understand the significance of Good Corporate Governance principles in enhancing the profitability and efficiency of company operations.

\section{REFERENCES}

1. Al Daoud, K. A., Ismail, K. N. I. K., \& Lode, N. A. (2015) The impact of internal corporate governance on the timeliness of financial reports of Indonesian firms: Evidence using audit and management report lags. Mediterranean Journal of Social
Sciences, 6(1), 430. https://doi. org/10.5901/mjss.2015.v6n1p430

2. Annisa, N., \& Kurniasih, L. (2012) Pengaruh corporate governance terhadap tax avoidance [The effect of corporate governance on tax avoidance]. Jurnal Akuntansi dan Auditing, 8(2), 123-136. Retrieved from https://ejournal.undip. ac.id/index.php/akuditi/article/ view/4352

3. Arevalo, J. A., \& Aravind, D. (2011). Corporate social responsibility practices in India: approach, drivers, and barriers. Corporate Governance: The 
International Journal of Business in Society, 11(4), 399-414. https://doi. org/10.1108/14720701111159244

4. Ashbaugh-Skaife, H., Collins, D. W., \& LaFond, R. (2006). The effects of corporate governance on firms' credit ratings. Journal of Accounting and Economics, 42(1-2), 203-243. https://doi. org/10.1016/j.jacceco.2006.02.003

5. Bals, L., \& Tate, W. (2017). Transparency. In L. Bals \& W. Tate (Eds.), Implementing Triple Bottom Line Sustainability into Global Supply Chains (pp. 90-155). Routledge, London, UK.

6. Bernstein, S., \& Cashore, B. (2012). Complex global governance and domestic policies: Four pathways of influence. International Affair, 88(3), 585604. https://doi.org/10.1111/ j.1468-2346.2012.01090.x

7. Bratton, W. W., \& McCahery, J. A. (2002). Comparative corporate governance and barriers to global cross reference. In J. A. McCahery, P. Moerland, T. Raaijmakers \& L. Renneboog (Eds.), Corporate Governance Regimes: Convergence and Diversity (pp. 23-54). Oxford University Press, Oxford, UK.

8. Calder, A. (2008). Corporate Governance: A Practical Guide to the Legal Frameworks and International Codes of Practice. Kogan Page Publishers, London, UK.

9. Carter, D. A., Simkins, B. J., \& Simpson, W. G. (2003). Corporate governance, board diversity, and firm value. Financial Review, 38(1), 33-53. https://doi. org/10.1111/1540-6288.00034

10. Chang, S. E. (2018). Indonesian Company Law. Routledge, Abingdon-on-Thames, UK.

11. Chi, C. W., Hung, K., Cheng, H. W., \& Lieu, P. T. (2015). Family firms and earnings management in Taiwan: Influence of corporate governance. International Review of Economics and Finance, 36, 88-98. https://doi.org/10.1016/j. iref.2014.11.009

12. Claessens, S., \& Fan, J. P. H. (2002). Corporate governance in Asia: A survey. International
Review of Finance, 3(2), 71-103. https://doi.org/10.1111/14682443.00034

13. Claessens, S., Djankov, S., \& Klingebiel, D. (2001). Financial restructuring in East Asia: halfway there? (SSRN Electronic Journal. Financial Sector Discussion Paper No. 3). http://dx.doi.org/10.2139/ ssrn. 282584

14. Creswell, J. W., \& Plano Clark, V. L. (2017). Designing and conducting mixed methods research. Sage Publications, California CA. Retrieved from https://www.sagepub.com/sites/ default/files/upm-binaries/10982_ Chapter_4.pdf

15. Cuervo, A. (2002). Corporate governance mechanisms: A plea for less code of good governance and more market control. Corporate Governance: An International Review, 10(2), 84-93. https://doi.org/10.1111/14678683.00272

16. Daily, C. M., Dalton, D. R., \& Cannella, Jr. A. A. (2003). Corporate governance: Decades of dialogue and data. Academy of Management Review, 28(3), 371-382. https://doi. org/10.2307/30040727

17. Daniel, W. E. (2003). Corporate governance in Indonesian listed companies-A problem of legal transplant. Bond Law Review, 15(1), 345-375. Retrieved from https://www.researchgate.net/ publication/27828939_Corporate_Governance_in_Indonesian_ Listed_Companies_-_A_Problem_of_Legal_Transplant

18. Darmadi, S. (2013). Corporate governance disclosure in the annual report: An exploratory study on Indonesian Islamic banks. Humanomics, 29(1), 4-23. https://doi.org/10.2139/ ssrn.1956254

19. De Andres, P., \& Vallelado, E. (2008). Corporate governance in banking: The role of the board of directors. Journal of Banking \& Finance, 32(12), 2570-2580. https://doi.org/10.1016/j.jbankfin.2008.05.008
20. Du Plessis, J. J., Hargovan, A., \& Harris, J. (2018). Principles of Contemporary Corporate Governance. Cambridge University Press, Cambridge.

21. Etikan, I., Musa, S. A., \& Alkassim, R. S. (2016). Comparison of convenience sampling and purposive sampling. American Journal of Theoretical and Applied Statistics, 5(1), 1-4. https://doi. org/10.11648/j.ajtas.20160501.11

22. Fan, J. P. H., \& Wong, T. J. (2005). Do external auditors perform a corporate governance role in emerging markets? Evidence from East Asia. Journal of Accounting Research, 43(1), 35-72. https://doi.org/10.1111/j.1475679x.2004.00162.x

23. Farrar, J. (2008). Corporate Governance: Theories, Principles and Practice. Oxford University Press, Oxford, UK.

24. Gillespie, P. (2012). The challenges of corporate governance in Indonesian oil palm: opportunities to move beyond legalism? Asian Studies Review, 36(2), 247-269. https://doi.org/10.1080/10357823. 2012.685447

25. Gilson, R. J. (2001). Globalizing corporate governance: Convergence of form or function. The American Journal of Comparative Law, 49(2), 329-358. https://doi.org/10.2307/840814

26. Gourevitch, P. A., \& Shinn, J. (2005). Political Power and Corporate Control: The New Global Politics of Corporate Governance. Princeton University Press, Princeton, NJ.

27. Haniffa, R. M., \& Cooke, T. E. (2005). The impact of culture and governance on corporate social reporting. Journal of Accounting and Public Policy, 24(5), 391-430. https://doi.org/10.1016/j.jaccpubpol.2005.06.001

28. Honggowati, S., Rahmawati, R., Aryani, Y. A., \& Probohudono, A. N. (2017). Corporate governance and strategic management accounting disclosure. Indonesian Journal of Sustainability Accounting and 
Management, 1(1), 23-30. https:// doi.org/10.28992/ijsam.v1i1.24

29. Iu, J., \& Batten, J. (2001). The implementation of OECD corporate governance principles in post-crisis Asia. Journal of Corporate Citizenship, 4, 47-62. Retrieved from https://www.jstor. org/stable/jcorpciti.4.47

30. Jao, R., \& Pagalung, G. (2011). Corporate Governance, Ukuran Perusahaan, Dan Leverage Terhadap Manajemen Laba Perusahaan Manufaktur Indonesia. Jurnal Akuntansi Dan Auditing, 8(1), 43-54. Retrieved from https:// ejournal.undip.ac.id/index.php/ akuditi/article/view/4346

31. Johnson, S., Boone, P., Breach, A., \& Friedman, E. (2000). Corporate governance in the Asian financial crisis. Journal of Financial Economics, 58(1-2), 141-186. https://doi.org/10.1016/S0304405X(00)00069-6

32. Joseph, C., Gunawan, J., Sawani, Y., Rahmat, M., Noyem, J. A., \& Darus, F. (2016). A comparative study of anti-corruption practice disclosure among Malaysian and Indonesian Corporate Social Responsibility (CSR) best practice companies. Journal of Cleaner Production, 112(4), 28962906. https://doi.org/10.1016/j. jclepro.2015.10.091

33. Kaihatu, T. (2006). Good corporate governance dan Penerapannya di Indonesia. Jurnal Manajemen dan Kewirausahaan, 8(1), 1-9. Retrieved from http://jurnalmanajemen.petra.ac.id/index.php/man/ article/view/16505

34. Luo, X., Wang, H., Raithel, S., \& Zheng, Q. (2015). Corporate social performance, analyst stock recommendations, and firm future returns. Strategic Management Journal, 36(1), 123-136. https://doi. org/10.1002/smj.2219

35. Mallin, C. A. (2011). Handbook on International Corporate Governance: Country Analyses. Edward Elgar Publishing, Cheltenham, UK.

36. Mitton, T. (2002). A crossfirm analysis of the impact of corporate governance on the East Asian financial crisis. Journal of Financial Economics, 64(2), 215-241. https://doi.org/10.1016/ S0304-405X(02)00076-4

37. Nasution, A. (2001). The meltdown of the Indonesian economy: Causes, impacts, responses, and lessons. ASEAN Economic Bulletin, 17(2), 148-162. Retrieved from https://www.jstor. org/stable/25773625

38. Nasution, M., \& Setiawan, D. (2007). Pengaruh corporate governance terhadap manajemen laba di industri perbankan Indonesia (26 p.). Simposium Nasional Akuntansi X. Makasar.

39. Okpara, J. O. (2011). Corporate governance in a developing economy: barriers, issues, and implications for firms. Corporate Governance: The International Journal of Business in Society, 11(2), 184-199. https://doi. org/10.1108/14720701111121056

40. Puspitaningrum, D., \& Atmini, S. (2012). Corporate governance mechanism and the level of internet financial reporting: Evidence from Indonesian companies. Procedia Economics and Finance, 2, 157-166. https://doi.org/10.1016/S22125671(12)00075-5

41. Rama, M. D. (2012). Corporate governance and corruption: Ethical dilemmas of Asian business groups. Journal of Business Ethics, 109(4). Retrieved from https://papers.ssrn.com/sol3/ papers.cfm?abstract_id $=1968680$

42. Ramage, D. E. (2007). Indonesia: Democracy first, good governance later. Southeast Asian Affairs, 1, 133-157. https://www.jstor.org/ stable/27913330

43. Retno, R. D., \& Priantinah, D. (2012). Pengaruh good corporate governance dan pengungkapan corporate social responsibility terhadap nilai perusahaan (Studi empiris pada perusahaan yang terdaftar di bursa efek Indonesia periode 2007-2010). Journal Nominal: Barometer Riset Akuntansi dan Manjemen
Indonesia, 1(2), 84-103. https:// doi.org/10.21831/nominal v1i2.1000

44. Rosser, A., \& Edwin, D. (2010). The politics of corporate social responsibility in Indonesia. The Pacific Review, 23(1), 1-22. https://doi. org/10.1080/09512740903398314

45. Sari, M., Lubis, A.F., Maksum, A., Lumbanraja, P., \& Muda, I. (2018). The influence of organization's culture and internal control to corporate governance and its impact on state-owned enterprises corporate. Journal of Applied Economic Sciences, 13(3), 673-684. https://doi.org/10.14505//jarle. v9\%202(32).30

46. Sawicki, J. (2009). Corporate governance and dividend policy in Southeast Asia pre-and post-crisis. The European Journal of Finance, 15(2), 211-230. https://doi. org/10.1080/13518470802604440

47. Siregar, S. V., \& Utama, S. (2008). Type of earnings management and the effect of ownership structure, firm size, and corporate governance practices: Evidence from Indonesia. The International Journal of Accounting, 43(1), 1-27. https://doi.org/10.1016/j. intacc.2008.01.001

48. Soesastro, H. (2003). Governance and the crisis in Indonesia In P. Drysdale (Ed.), Reform and Recovery in East Asia. London: Routledge.

49. Waagstein, P. R. (2011). The mandatory corporate social responsibility in Indonesia: Problems and implications. Journal of Business Ethics, 98(3), 455-466. https://doi.org/10.1007/ s10551-010-0587-x

50. Wahyudin, A., \& Solikhah, B. (2017). Corporate governance implementation rating in Indonesia and its effects on financial performance. Corporate Governance: The International Journal of Business in Society, 17(2), 250-265. https://doi. org/10.1108/CG-02-2016-0034

51. Walter, A. (2008). Governing Finance: East Asia's Adoption of 
International Standards. Cornell University Press, Ithaca, NY.

52. Wu, X. (2005a). Corporate governance and corruption: A cross-country analysis. Governance, 18(2), 151-170. Retrieved from https://ssrn.com/ abstract $=921520$

53. Wu, X. (2005b). Political institutions and corporate governance reform in Southeast Asia. In K. L. Ho (Ed.), Reforming Corporate Governance in Southeast Asia: Economics, Politics and Regulation (pp. 16-37). Institute of Southeast Asia Studies (ISEAS) Publications, Singapore. Retrieved from https://ssrn.com/abstract $=921522$

54. Wulandari, N. (2006). Pengaruh indikator mekanisme corporate governance terhadap kinerja perusahaan publik di Indonesia. Focus Ekonomi, 1(2), 120-136. http://ejournal.stiepena.ac.id/index.php/fe/article/view/18/18

55. Xie, B., Davidson III, W.N., \& DaDalt, P. J. (2003). Earnings management and corporate governance: The role of the board and the audit committee. Journal of Corporate Finance, 9(3), 295316. https://doi.org/10.1016/ S0929-1199(02)00006-8
56. Young, M. N., Ahlstrom, D., \& Bruton, G. D. (2004). The globalization of corporate governance in East Asia: The "transnational" solution. Management and International Review, 31-50. https://doi. org/10.1007/978-3-322-909978_3

57. Zattoni, A., \& Cuomo, F. (2010). How independent, competent and incentivized should nonexecutive directors be? An empirical investigation of good governance codes. British Journal of Management, 21(1), 63-79. https://doi.org/10.1111/j.14678551.2009.00669.x 